\title{
Antibacterial activity of polypyrrole-based nanocomposites: a mini-review
}

\author{
Fernando Antonio Gomes da Silva Júnior ${ }^{1}$ (D), Simone Araújo Vieira ${ }^{1}$ (D), Sônia de Avila Botton² (D), \\ Mateus Matiuzzi da Costa ${ }^{1}$ (D) and Helinando Pequeno de Oliveira ${ }^{1 *}$ (D)
}

\begin{abstract}
1 Institute of Materials Science, Universidade Federal do Vale do São Francisco - UNIVASF, Juazeiro, BA, Brasil ${ }^{2}$ Postgraduate Program in Veterinary Medicine - PPGMV, Department of Preventive Veterinary Medicine DMVP, Universidade Federal de Santa Maria - UFSM, Santa Maria, RS, Brasil

*helinando.oliveira@univasf.edu.br
\end{abstract}

\begin{abstract}
The development of polypyrrole-based nanocomposites as alternative antibacterial agents represents a promising strategy to be applied against the prevailing multi-resistant bacteria. Herein, it is reported the most recent development of antibacterial materials based on the combination of polypyrrole and different fillers (metal nanoparticles, carbon nanotubes, and polysaccharides) and strategies to improve their action (such as light and electrical stimulus). The synergistic interaction of electrostatic forces provided by charged polypyrrole combined with the permeation of nanoparticles through the cell wall favors the leakage of cytoplasmic components and reinforces the antibacterial activity of the resulting material, observed in all-organic composites of polypyrrole and chitosan that reached superior performance against Escherichia coli $\left(10^{8} \mathrm{CFU}\right)$ or metal-polymer composites (polypyrrole-palladium) with an outstanding performance against different types of bacteria. The development of binary and ternary composites is explored to potentialize the antibacterial synergy of components.
\end{abstract}

Keywords: antibacterial, carbon nanotubes, nanocomposites, polypyrrole, silver nanoparticles.

How to cite: Silva Júnior, F. A. G., Vieira, S. A., Botton, S. A., Costa, M. M., \& Oliveira, H. P. (2020). Antibacterial activity of polypyrrole-based nanocomposites: a mini-review. Polímeros: Ciência e Tecnologia, 30(4), e2020048. https://doi.org/10.1590/0104-1428.08020

\section{Introduction}

The resistance against antibiotics developed by microorganisms has been considered an emerging worldwide crisis in a scenario of the scarcity in the production of new antibiotics ${ }^{[1-5]}$, one of the most relevant topics for world public health ${ }^{[6,7]}$. As a consequence, the development of strategies to circumvent the use of antibiotics becomes critically important $t^{[2,5,8-10]}$. The substitution of conventional drugs by chemical composites at nanoscale introduces important advantages to inactivate new mechanisms of resistance acquired by several microorganisms ${ }^{[1]}$.

In this direction, the use of conducting polymers (isolated, combined, and in association with antibiotics) as antibacterial agents has been considered a promising methodology for new antibacterial systems ${ }^{[1-19]}$. In particular, polypyrrole has been considered as one of the most important organic materials in the literature, being successfully explored in plenty of applications, making use of its superior electrical properties ${ }^{[18]}$, ease synthesis, high stability under ambient conditions, and good redox properties ${ }^{[20]}$.

The most common applications of polypyrrole involve the development of electrodes for supercapacitors ${ }^{[21]}$, sensors $^{[22]}$, anticorrosive surfaces ${ }^{[23]}$, removal of heavy metal ions and traces from wastewater ${ }^{[24]}$, adsorbent for dyes ${ }^{[25]}$, selective adsorption of components ${ }^{[26]}$, electromagnetic wave absorbers ${ }^{[27]}$ and antibacterial agents ${ }^{[28-30]}$.
In the last application, the use of antimicrobial agents is strongly motivated in different areas such as medical, food, and textiles due to the scarcity of conventional antibiotics. The development of these alternative materials is guided by characteristic environmentally friendly behavior, high biodegradability, and the intrinsic activity against antibioticresistant organisms. These applications involve the disinfection of water $^{[31]}$, for food packing ${ }^{[32]}$, for inhibition of methicillin-resistant Staphylococcus aureus ${ }^{[33]}$, and antibacterial textiles ${ }^{[34]}$ based on poly(lactic acid) incorporated chitosan nanocomposites ${ }^{[35]}$.

The intrinsic antibacterial activity of polypyrrole is a consequence of the oxidative polymerization of pyrrole monomers: positive charges are created at fixed intervals of three to five monomers along the main chain of polypyrrole ${ }^{[36,37]}$. This relevant cationic behavior confers an important antibacterial activity for the resulting polymeric chain, described as follows.

\subsection{Mechanisms of antibacterial activity of polypyrrole- based systems}

The resulting positive net charge of chains of polypyrrole electrostatically interacts with the overall surface charge of bacterial wall cell that is negatively chaged ${ }^{[36]}$. Based on this aspect, the bioactivity of polypyrrole has been attributed to 
the resulting positive charged species along the synthesized chains ${ }^{[38]}$. These species are stabilized by the introduction of anions that act as counter-ions such as $\mathrm{Cl}^{-}$and $\mathrm{SO}_{4}^{-}$. The overall process of antibacterial can be described by the following steps:

The initial electrostatic interaction between conducting polymer and bacteria results in the adhesion of microorganisms to the polymer surface. The physical interaction step is followed by the diffusion of nanoparticles and active counter-ions particles in the direction of the cytoplasmic membrane. This process is established by the permeation of the species into the cell, which provokes the death of bacteria ${ }^{[36]}$. The general scheme for the overall process of attachment of bacterial cells on the polypyrrole film surface is drawn in Figure 1 in which is indicated that interaction with the charged surface and the diffusion of reactive into the cell wall results in the death (leakage of vital components from the cells).

The direct measurement of the zeta potential of the resulting material (polypyrrole-based composite) denotes important information about the overall surface charge signal (positive or negative) and consequently the overall potential for use as an antibacterial. Bin-Jumah et al. ${ }^{[39]}$ reported the use of ocular chitosan nanoparticles in which the zeta potential is explored to determine the presence of positively charged chitosan groups on the external surface of particles and to infer the level of bioadhesion. To reach the desired condition in the zeta potential response (stability and positively charged surface), it worth mentioning that antibacterial activity of these materials is $\mathrm{pH}$-dependent, being possible to reach the condition of protonation or deprotonation of polypyrrole (from positively charged to neutral) with direct consequences on bioadhesion: negative zeta potential is observed for both Gram-positive bacteria (in the response of prevailing polysaccharides) or Gram-negative bacteria (teichoic acids bonded to the peptidoglycan layer) ${ }^{[40]}$.

Despite this relevant intrinsic property of polypyrrole, the morphology (aggregation level) of polymeric chains represents a critical drawback that needs to be circumvented by the use of specific formulations, being considered the possibility of production of polypyrrole-based nanoparticles ${ }^{[41]}$. The incorporation of polypyrrole as a filler or primary matrix for chemical modification is explored from the production of composites with carbon derivatives (such as carbon nanotubes and graphene oxide), metal nanoparticles (silver and palladium), natural materials (chitosan-based matrix), and from interaction with other polymers (such as polyaniline) - the different possibilities for the production of effective antibacterial composites by incorporation of additives/ fillers are summarized in Figure 2.

Besides, the interaction of components in the composite opens the possibility of the synergistic interaction towards more effective antibacterial devices. In the following section, it is discussed about the most relevant strategies for the optimization of polypyrrole-based composites as antibacterial agents.

\section{Polypyrrole-based nanocomposites}

The production of polypyrrole/ metal nanoparticlebased composites represents an important step towards the development of superior multifunctional materials based on the synergistic interaction of components to reach potential performance against bacterial growth, proliferation, and the following cell death. With this aim, the polypyrrole has been



Figure 1. Scheme of electrostatic processes involved in the general mechanism of antibacterial activity of polypyrrole and the following step of cell death - leakage of DNA and vital components. 


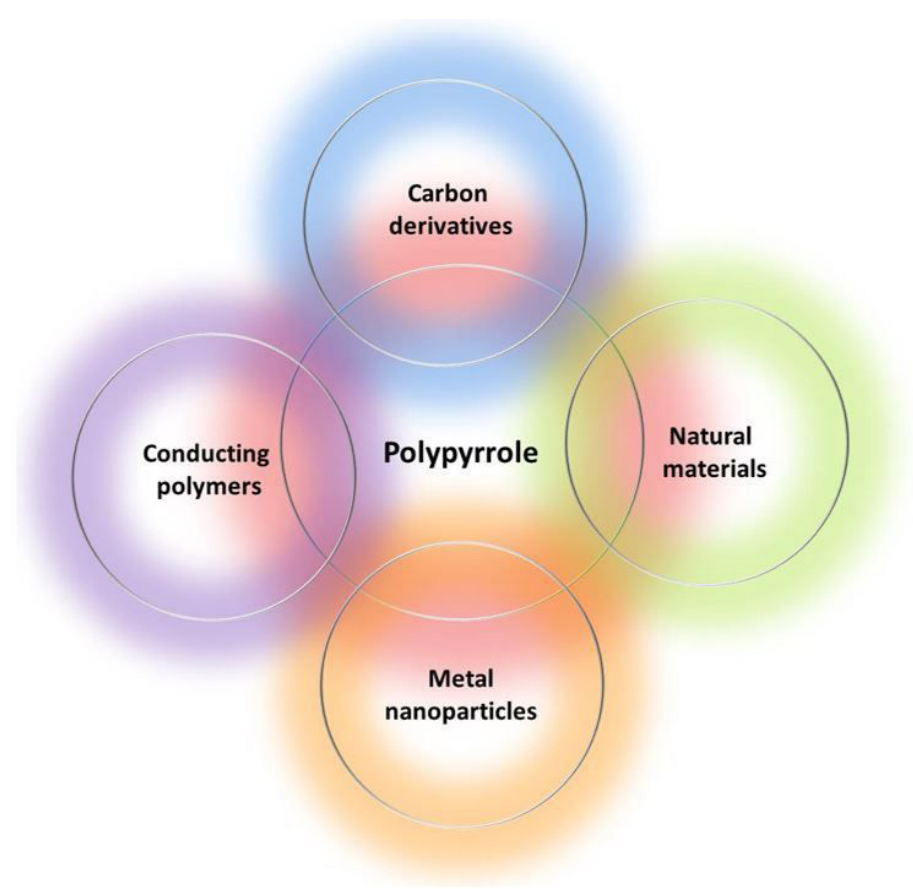

Figure 2. Interaction of polypyrrole and chemical compounds for the development of effective antibacterial nanocomposites.

combined with different elements such as iron oxide ${ }^{[42]}$, zinc oxide $^{[43]}$, palladium ${ }^{[44]}$, and silver nanoparticles ${ }^{[45-47]}$. The advantage related to the production of multifunctional metal/ polymer nanocomposites with antibacterial activity regards the incorporation of intrinsic properties of inorganic phases, such as the magnetic separation of $\mathrm{Fe}_{3} \mathrm{O}_{4}$-based composites, the photocatalytic activity of $\mathrm{ZnO}$-based samples, and the plasmonic properties of silver-based composites.

Despite all of the efforts to understand the general mechanism involved in bacterial cell death induced by these experimental prototypes, the overall process is not completely identified. The most accepted hypothesis is attributed to the strong diffusive activity of metal nanoparticles (palladium, silver, or iron oxide) that migrate in direction to bacteria and permeate into the cell wall to provokes the leakage of the cytoplasmic components which is facilitated by strong "adhesive" properties of conducting polymer layer that electrostatically attracts the oppositely charged bacterial cells.

Hasantabar et al. ${ }^{[42]}$ reported the development of an interesting core-shell-shell structure in which iron oxide nanoparticles are coated by a first thin layer of polyxanthone triazole for the following deposition of polypyrrole layer. The authors attributed the superior performance in antibacterial activity to the mutual response of pyrrolinium, triazole ring, xanthone, and $\mathrm{Fe}_{3} \mathrm{O}_{4}$ nanoparticles that damage the cell wall, provoking the leakage of vital components and the death of the cells.

Moreover, the combination of metal oxide nanoparticles into polypyrrole-based composites, such as zinc oxide into polypyrrole/ chitosan composition can be considered as a promising strategy not only for improved antibacterial assays but also for anticancer performance ${ }^{[43]}$. The reinforcement provided by $\mathrm{ZnO}$ nanoparticles has been attributed to the oxidative stress provoked by nanoparticles after permeation through the cell barrier, which restricts bacterial growth.

The most common metal/ polypyrrole nanocomposites (polypyrrole/ palladium and polypyrrole/ silver nanoparticles) are described in the following sections.

\subsection{Polypyrrole/palladium (PPy-Pd)}

Nanocomposites of polypyrrole and palladium have been intensively explored in the literature for different applications such as catalysts ${ }^{[48,49]}$, electrocatalysts ${ }^{[50]}$, antibacterial ${ }^{[44]}$, and antibiofilm activity ${ }^{[51]}$. These compounds can incorporate magnetic properties from ternary composites of reusable ironconducting polymer-noble metal ${ }^{[48]}$, different disposition of components such as sandwich structured Pd-PPy-Pd ${ }^{[50]}$, and more elaborate experimental systems as scaffolds (association of PPy, Pd and reduced graphene oxide) with antibiofilm properties applied in implants ${ }^{[51]}$. Despite these relevant applications, the typical procedure for nanocomposites synthesis can be considered in a simple step process: the micro emulsion-based polymerization procedure mediated by $\mathrm{Fecl}_{3}$ induces the polymerization of polypyrrole on $\mathrm{Pd}$ nanostructures, as reported in Ref ${ }^{[44]}$.

The interaction of polypyrrole and Pd in composites is justified by the strong antibacterial activity of palladium nanoparticles. As described in the literature, the antibacterial activity of palladium is size-dependent ${ }^{[52]}$ with interesting results for inhibition of bacteria due to the interaction of Pd nanoparticles with bacterial cell wall - in this case, the interaction of Pd nanoparticles and phosphor/ sulfur moieties causes the death of the cells. As a resistance mechanism from specific classes of bacteria (such as E. coli), it is reported the possibility of the use of efflux complexes that pump biocidal nanoparticles from cells ${ }^{[52]}$ and can be explored as 
a source for superior performance of these nanoparticles against $S$. aureus cells.

Superior antibacterial properties were observed for PPy-Pd composites as a consequence of the incorporation of Pd nanoparticles into the polymeric matrix, making use of advantages such as the electrostatic interaction between polymer surface and bacterial cell wall for the following step of nanoparticles release $\mathrm{e}^{[4]]}$. The overall process favors not only the antibacterial activity but also favors the antibiofilm activity since the process tends to be established in the polymer surface, due to the attraction of negatively charged cells of bacteria.

\subsection{Polypyrrole-silver nanoparticles (PPy-AgNPS)}

The antibacterial activity of silver has been extensively reported in the literature ${ }^{[53-55]}$. As previously reported for Pdbased systems, the effective action of silver against bacteria is a size-dependent process in which particles with a size in the order of $7 \mathrm{~nm}$ reaches the nuclear content and release $\mathrm{Ag}^{+}$ions, being favored by the high available surface area of nanoparticles ${ }^{[53]}$. Based on this condition, the incorporation of silver nanoparticles on the polymeric matrix depends on the aggregation level of structures that can be conveniently guided from the growth of polymeric structures ${ }^{[56]}$.

To reach adequate dispersion of silver nanoparticles on different morphology of supports, different strategies of synthesis have been established, as follows:

The production of cylindrical polymeric templates decorated with silver chloride $(\mathrm{AgCl})^{[57]}$ makes use of the selfaggregation of methyl orange to form cylinders in microscale which are explored as templates for the polymeric growth. With the use of ammonium persulfate as the oxidizing agent in the presence of silver nitrate and monomers of pyrrole, the polymerization takes place and the polypyrrole chains grown on tubular supports, acquiring the morphology of hollow tubes decorated with $\mathrm{AgCl}$ nanoparticles.

Another alternative is reported by J. Upadhyay et al. ${ }^{[58]}$ that produced silver nanoparticles-decorated polypyrrole nanocomposites (PPy-AgNPs) from in situ reductions of silver nitrate. The authors identified a direct relationship between the amounts of silver in the composite with the overall antibacterial activity of the resulting material. The electrostatic interaction between the conductive layer of polypyrrole and negatively charged bacteria and the release of $\mathrm{Ag}^{+}$ions into the cells are general mechanisms for this antibacterial system.

Another interesting property for the decorated nanostructures with silver nanoparticles is reported by Saad et al. ${ }^{[59]}$. For this process, silica nanoparticles were impregnated with pyrrole monomers while silver nitrate was explored as a photosensitizer. The polymerization was initiated by ultraviolet irradiation and silica@PPy composites in which silver nanoparticles were synthesized as a result of the polymerization.

\subsection{Polypyrrole/chitosan (PPy-chitosan)}

Chitosan is a hydrophilic polysaccharide derived from chitin and extensively reported as a natural material with antibacterial activity ${ }^{[60,61]}$. The mechanism of bacterial inhibition is similar to the polypyrrole due to the high-density of cationized amines on the chitosan surface, which results in a positively charged surface that affects the attached bacteria inducing osmotic imbalances and provoking the hydrolysis of the peptidoglycan layer with the following leakage of intracellular electrolytes ${ }^{[62]}$. As observed for previously reported systems, the aggregation represents a strong limiting factor due to the inhibition of active sites for the adhesion of microorganisms. The development of composites based on the interaction of chitosan and conducting polymer represents an important strategy to improve the density of active sites for bacterial adhesion ${ }^{[33-65]}$.

Soleimani et al ${ }^{[66]}$ reported the preparation of polypyrrole/ chitosan nanocomposites, exploring the chemical polymerization of polypyrrole that uses the chitosan as a substrate. The synergistic interaction of components (with a higher density of electrostatic active sites) results in superior performance for the composite, that follows the order (in terms of antibacterial activity): PPy-chitosan> pure $\mathrm{PPy}>$ chitosan. The presence of chitosan creates the effect of a phospholipid sponge, in which negatively charged phospholipid cells attached to cell membrane migrated in direction to the porous structure rich in charged polymeric chains and amine groups.

\subsection{Polypyrrole/ carbon nanotubes (PPy-CNT)}

Carbon nanotubes have been successfully applied against groups of microorganisms (such as bacteria, protozoa, and viruses $)^{[67,68]}$ in planktonic and biofilm forms with a primary mechanism based on the physical elements that penetrate the membrane and lead to the leakage of components such as protein and nucleic acid leakage ${ }^{[69]}$. However, the poor solubility degree of CNT in different solvents inhibits its potential antibacterial activity (characteristic of isolated nanotubes). To circumvent this limitation, a promising strategy refers to the incorporation of CNT into the polymer as a filler component ${ }^{[67]}$. Thus, the adequate disposition of CNT into the polymeric matrix avoids further bundle formation steps and favors the effective physical disruption of the bacterial membrane. The development of composites based on PPy and CNT makes use of superior properties of both materials, such as high conductivity, potential antibacterial activity, and strong absorption of light in the near-infrared region.

Tondro et al. ${ }^{[69]}$ combined these properties and incorporated the components in a phototherapy treatment based on IR light irradiation. The direct incidence of irradiation combines the effect of physical rupture of cells (from CNT), the electrostatic attraction of polypyrrole to the bacterial cells, and the improved generation rate of reactive oxygen species (ROS) induced by laser irradiation. Therefore, it is observed a reduction in the viability of the cells, as a result of protein and nucleic acid leakage and ROS production inhibit vital processes in the bacteria ${ }^{[69]}$.

\subsection{Polypyrrole-based ternary composites}

As observed for polypyrrole-based systems, the intrinsic antibacterial activity of PANI has been observed for emeraldine salt form in the response of high doping level of this structure, which offers a high density of sites for electrostatic interaction with bacterial cells and favors 
the production of hydrogen peroxidase that participate in the reactive oxygen species activity (cell damage and cell death) ${ }^{[70-72]}$. On the other hand, the high conductivity of PANI perturbs the flow of electrons in bacterial cells, establishing an alternative mechanism for bacterial control.

The development of ternary nanocomposites (structures with three active antibacterial agents) can be explored as an important source for antibacterial activity and also as systems with two- and three-level of interaction between components $^{[73]}$.

There are at least two important possibilities of combination: a complete electrostatic sponge-like structure (a combination of conducting polymers and chitosan) or a polymeric template with nanoparticles and physical agents (polypyrrole, silver nanoparticles, and carbon nanotubes), described as follows.

Kumar et al. ${ }^{[74]}$ reported the synthesis of composites of polypyrrole containing polyaniline that were functionalized with chitosan to act as ternary antibacterial agents. The comparison of the performance of ternary with binary and isolated compounds follows the order: chitosan+PA $\mathrm{NI}+\mathrm{PPy}>\mathrm{PANI}+\mathrm{PPy}>\mathrm{PPy}>\mathrm{PANI}>$ chitosan, confirming the potential of isolated polypyrrole and a promising synergistic interaction with chitosan and polyaniline in a better antibacterial experimental system.

The interaction of carbon nanotubes, nanoparticles, and polymeric surface ${ }^{[75]}$ was reported from oxidative polymerization (in situ) of polypyrrole induced by reaction with silver nitrate in a matrix loaded with different amounts of carbon nanotubes. The resulting composites $\left(\mathrm{CNT}_{0-60} / \mathrm{PPy} / \mathrm{AgNPs}\right)$ demonstrated a good synergistic interaction between polypyrrole and CNT that is favored by the available surface area of carbon nanotubes in an electroactive matrix of polypyrrole decorated with silver nanoparticles. The performance of recent state-of-art in the area for corresponding systems is compared in Table 1, which described the type of synthesis and the resulting inhibition halo for each composition.

As reported in the literature, the biocidal activity of polypyrrole is derived from its intrinsic positive charge. Thus, the attachment with cells disrupts the negatively charged cytoplasmic membrane of bacteria and causes the leakage of internal components, leading to the death of bacteria ${ }^{[78]}$. However, Gram-negative bacteria such as E. coli present an extracellular membrane that reduces the total negative charge per cell. This process makes these organisms less prone to be electrostatically adsorbed on positive charges at the surface of composites ${ }^{[79]}$. The complexity of the outer membrane of Gram-negative bacteria, by selective proteins and efflux systems, is also a prohibitive barrier for inward diffusion of drugs, acting as an inducing factor for resistance to antibacterial agents. In consequence, concentrationdependent processes and the synergistic interaction with nanosized-scale structures represent important strategies to circumvent this limitation against Gram-negative species. These antibacterial new barriers can be categorized as dependent on different processes, summarized as follows:

- Incorporation of diffusive fillers;

- Interaction with physical processes;

- Incorporation of fillers for ROS production;

- Development of porous supports that minimize the aggregation level of antibacterial components.

The doping level of conducting polymers is a key role in the overall process since it confers relevant properties not only in terms of electronic properties but also to increase the diffusive counter ions concentration. These species are relevant in the following step of attachment of organisms on conducting polymer surface, being responsible by the penetration and the subsequent step of inhibition of vital processes in the organisms. Besides that, the interaction of conducting polymers and carbon nanotubes introduces an additional advantage related to the physical rupture of the cytoplasmic layer and the following leakage of internal components that are additional advantages of the toxic activity of carbon nanotubes. It refers to the incorporation of some external excitation conditions that can improve the performance of these devices.

\subsection{The effect of light and electric field on the antibacterial activity of polypyrrole-based composites}

The introduction of an external excitation can be conveniently addressed to optimize the overall antibacterial activity of the composites. The interaction with light, in the infrared region, makes use of strong absorbance of conducting polymer-based systems, promoting the additional ROS generation $^{[69]}$. Another important aspect that can be explored in high conductivity-based polymeric antimicrobial agent refers to the association of thermal effects and ROS-induced

Table 1. Different systems containing polypyrrole (PPy), type of synthesis, and amount of each composite are used to inhibit different bacterial organisms.

\begin{tabular}{|c|c|c|c|c|c|c|}
\hline Material & Synthesis & Mass (mg) & Bacterium & CFU & $\begin{array}{c}\text { Inhibition halo } \\
(\mathrm{mm})\end{array}$ & Ref. \\
\hline \multirow[t]{4}{*}{ PPy-Pd } & Chemical polymerization & 100 & Bacillus spp. & 108 & 23 & [2] \\
\hline & & & S. aureus & & 10 & \\
\hline & & & E. coli & & 16 & \\
\hline & & & K.pneumoniae & & 14 & \\
\hline PPy-AgCl & Reactive Self-degradation & - & E. coli & 108 & 23 & [76] \\
\hline PPy- NTs: Ag-NPs & In situ reduction & 100 & S. aureus & 108 & 23 & [77] \\
\hline PPy-chitosan & Chemical Polymerization & 100 & E. coli & 108 & 20 & [18] \\
\hline PPy-silica-AgNPs & Oxidative Photopolymerization & $200-300$ & E. coli & 107 & 10 & [24] \\
\hline $\mathrm{CNT}_{0-60} / \mathrm{PPy} / \mathrm{Ag}$ & Chemical Polymerization & 200 & E. coli & 108 & - & [58] \\
\hline
\end{tabular}


generation by the external electric field. Da Silva et al. ${ }^{[19]}$ reported the electrochemical modulation of cationic species by an external low electrical field. Similar to this phenomenon in photodynamic phototherapy, polypyrrole-based systems can act as electrical heating sources with the advantages of metal-free electrodes.

These strategies are favored by increasing surface area for resulting devices. With this aim, the development of substrates for polymer deposition with high surface area circumvents the limiting aspect related to the progressive adhesion of bacteria on the polymer surface. The deposition of conducting polymers on porous polyurethane (as an example) offers a bulky structure to the impregnation with microorganisms and treatment. The combination of these strategies favors the increase in the intrinsic and stronger antimicrobial activity of conducting polymers that can be considered as promising candidates for alternative strategies against increasing antibiotic-resistant organisms.

\section{Conclusions}

The development of alternative antibacterial agents based on conducting polymers represents a promising strategy to circumvent the increasing resistance to antibiotics, which can be enriched by the incorporation of fillers and physical methods such as phototherapy and electrical excitation to avoid limitations related to the progressive attachment of microorganisms in the polymer surface - strategies of interest in different areas such as medical, food and textile industries. Promising options to reach adequate activity involve the development of substrates with high porosity degree, surface area, and flexibility to be applied as prototypes for wound dressing devices activated by different external excitation for use in the topical treatment of microbial infections. Based on these aspects, the interaction of carbon derivatives, metal nanoparticles and polypyrrole immersed in porous substrate represents an important prototype for antibacterial applications, due to the high surface area, high conductivity, intrinsic activity of polypyrrole (for electrostatic interaction) and carbon nanotubes (for physical rupture of the membrane) in composites that can be optimized in terms of heat treatment and ROS generation for effective rupture and leakage of components from microorganisms. The polycationic behavior of the resulting material can be favored by both components, as observed for PPy-chitosan composites that present good performance in the response of positive zeta potential of the arrangement, favoring the electrostatic interaction with oppositely charged species (Gram-positive and Gram-negative bacteria).

\section{Acknowledgements}

This work was partially supported by Brazilian funding agency Conselho Nacional de Desenvolvimento Científico e Tecnológico - CNPq.

\section{References}

1. Huh, A. J., \& Kwon, Y. J. (2011). "Nanoantibiotics": A new paradigm for treating infectious diseases using nanomaterials in the antibiotics resistant era. Journal of Controlled Release,
156(2), 128-145. http://dx.doi.org/10.1016/j.jconrel.2011.07.002. PMid:21763369.

2. Munguia, J., \& Nizet, V. (2017). Pharmacological Targeting of the Host-Pathogen Interaction: Alternatives to classical antibiotics to combat drug-resistant superbugs. Trends in Pharmacological Sciences, 38(5), 473-488. http://dx.doi. org/10.1016/j.tips.2017.02.003. PMid:28283200.

3. Ventola, C. L. (2015). Antibiotic Resistance Crisis Part 1: causes and Threats. $P \& T, 40(4), 277-283$. PMid:25859123.

4. Bansal, R., Jain, A., Goyal, M., Singh, T., Sood, H., \& Malviya, H. (2019). Antibiotic abuse during endodontic treatment: A contributing factor to antibiotic resistance. Journal of Family Medicine and Primary Care, 8(11), 3518-3524. http://dx.doi. org/10.4103/jfmpc.jfmpc_768_19. PMid:31803645.

5. Andersson, D. I. (2003). Persistence of antibiotic resistant bacteria. Current Opinion in Microbiology, 6(5), 452-456. http://dx.doi.org/10.1016/j.mib.2003.09.001. PMid:14572536.

6. Abbott, A. (2005). Medics braced for fresh superbug. Nature, 436(7052), 758. http://dx.doi.org/10.1038/436758a. PMid:16094326.

7. Ferber, D. (2010). From pigs to people: the emergence of a new superbug. Science, 329(5995), 1010-1011. http://dx.doi. org/10.1126/science.329.5995.1010. PMid:20798295.

8. Bhardwaj, K., Vinothkumar, K., \& Rajpara, N. (2013). Bacterial quorum sensing inhibitors: attractive alternatives for control of infectious pathogens showing multiple drug resistance. Recent Patents on Anti-infective Drug Discovery, 8(1), 68-83. http:// dx.doi.org/10.2174/1574891X11308010012. PMid:23394143.

9. Hemeg, H. A. (2017). Nanomaterials for alternative antibacterial therapy. International Journal of Nanomedicine, 2017(12), 82118225. http://dx.doi.org/10.2147/IJN.S132163. PMid:29184409.

10. Lam, S. J., O’Brien-Simpson, N. M., Pantarat, N., Sulistio, A., Wong, E. H. H., Chen, Y. Y., Lenzo, J. C., Holden, J. A., Blencowe, A., Reynolds, E. C., \& Qiao, G. G. (2016). Combating multidrug-resistant Gram-negative bacteria with structurally nanoengineered antimicrobial peptide polymers. Nature Microbiology, 12(11), 16162. http://dx.doi.org/10.1038/ nmicrobiol.2016.162. PMid:27617798.

11. Maráková, N., Humpolíček, P., Kašpárková, V., Capáková, Z., Martinková, L., Bober, P., Trchová, M., \& Stejskal, J. (2017). Antimicrobial activity and cytotoxicity of cotton fabric coated with conducting polymers, polyaniline or polypyrrole, and with deposited silver nanoparticles. Applied Surface Science, 396, 169-176. http://dx.doi.org/10.1016/j.apsusc.2016.11.024.

12. Gizdavic-Nikolaidis, M. R., Bennett, J. R., Swift, S., Easteal, A. J., \& Ambrose, M. (2011). Broad spectrum antimicrobial activity of functionalized polyanilines. Acta Biomaterialia, 7(12), 4204-4209. http://dx.doi.org/10.1016/j.actbio.2011.07.018. PMid:21827876.

13. Sánchez-Jiménez, M., Estrany, F., Borràs, N., Maiti, B., Díaz Díaz, D., Del Valle, L. J., \& Alemán, C. (2019). Antimicrobial activity of poly(3,4-ethylenedioxythiophene) n-doped with a pyridinium-containing polyelectrolyte. Soft Matter, 15(38), 7695-7703. http://dx.doi.org/10.1039/C9SM01491H. PMid:31502620.

14. Mohammadi, B., Pirsa, S., \& Alizadeh, M. (2019). Preparing chitosan-polyaniline nanocomposite film and examining its mechanical, electrical, and antimicrobial properties. Polymers \& Polymer Composites, 27(8), 507-517. http://dx.doi. org/10.1177/0967391119851439.

15. De Silva, C. C., Israni, N., Zanwar, A., Jagtap, A., Leophairatana, P., Koberstein, J. T., \& Modak, S. M. (2019). "Smart" polymer enhances the efficacy of topical antimicrobial agents. Burns, 45(6), 1418-1429. http://dx.doi.org/10.1016/j.burns.2019.04.013. PMid:31230802. 
16. Ramos, A. R., Tapia, A. K. G., Piñol, C. M. N., Lantican, N. B., del Mundo, M. L. F., Manalo, R. D., \& Herrera, M. U. (2019). Morphological, electrical and antimicrobial properties of polyaniline-coated paper prepared via a two-pot layer-bylayer technique. Materials Chemistry and Physics, 238, 121972. http://dx.doi.org/10.1016/j.matchemphys.2019.121972.

17. Da Silva, F. A. G. Jr, Queiroz, J. C., Macedo, E. R., Fernandes, A. W. C., Freire, N. B., Da Costa, M. M., \& De Oliveira, H. P. (2016). Antibacterial behavior of polypyrrole: the influence of morphology and additives incorporation. Materials Science and Engineering C, 62, 317-322. http://dx.doi.org/10.1016/j. msec.2016.01.067. PMid:26952429.

18. Lima, R. M. A. P., Alcaraz-Espinoza, J. J., Da Silva, F. A. G. Jr, \& De Oliveira, H. P. (2018). Multifunctional Wearable Electronic Textiles Using Cotton Fibers with Polypyrrole and Carbon Nanotubes. ACS Applied Materials \& Interfaces, 10(16), 13783-13795. http://dx.doi.org/10.1021/acsami.8b04695. PMid:29620858.

19. da Silva, F. A. G. Jr, Alcaraz-Espinoza, J. J., da Costa, M. M., \& de Oliveira, H. P. (2017). Synthesis and characterization of highly conductive polypyrrole-coated electrospun fibers as antibacterial agents. Composites. Part B, Engineering, 129, 143-151. http://dx.doi.org/10.1016/j.compositesb.2017.07.080.

20. Valiūnienė, A., Rekertaitė, A. I., Ramanavičienè, A., Mikoliūnaitè, L., \& Ramanavičius, A. (2017). Fast Fourier transformation electrochemical impedance spectroscopy for the investigation of inactivation of glucose biosensor based on graphite electrode modified by Prussian blue, polypyrrole and glucose oxidase. Colloids and Surfaces. A, Physicochemical and Engineering Aspects, 532, 165-171. http://dx.doi.org/10.1016/j. colsurfa.2017.05.048.

21. Huang, Y., Li, H., Wang, Z., Zhu, M., Pei, Z., Xue, Q., Huang, Y., \& Zhi, C. (2016). Nanostructured Polypyrrole as a flexible electrode material of supercapacitor. Nano Energy, 22, 422438. http://dx.doi.org/10.1016/j.nanoen.2016.02.047.

22. Sakhraoui, H. E. E. Y., Mazouz, Z., Attia, G., Fourati, N., Zerrouki, C., Maouche, N., Othmane, A., Yaakoubi, N., Kalfat, R., Madani, A., \& Nessark, B. (2019). Design of L-Cysteine and acrylic acid imprinted Polypyrrole sensors for picomolar detection of lead ions in simple and real media. IEEE Sensors Journal, 20(8), 4147-4155. http://dx.doi.org/10.1109/ JSEN.2019.2961984.

23. Zhu, Q., Li, E., Liu, X., Song, W., Li, Y., Wang, X., \& Liu, C. (2020). Epoxy coating with in-situ synthesis of polypyrrole functionalized graphene oxide for enhanced anticorrosive performance. Progress in Organic Coatings, 140, 105488. http://dx.doi.org/10.1016/j.porgcoat.2019.105488.

24. Aigbe, U. O., Das, R., Ho, W. H., Srinivasu, V., \& Maity, A. (2018). A novel method for removal of $\mathrm{Cr}(\mathrm{VI})$ using polypyrrole magnetic nanocomposite in the presence of unsteady magnetic fields. Separation and Purification Technology, 194, 377-387. http://dx.doi.org/10.1016/j.seppur.2017.11.057.

25. Szczęśniak, B., Osuchowski, Ł., Choma, J., \& Jaroniec, M. (2018). Highly porous carbons obtained by activation of polypyrrole/reduced graphene oxide as effective adsorbents for CO2, H2 and C6H6. Journal of Porous Materials, 25(2), 621-627. http://dx.doi.org/10.1007/s10934-017-0475-1.

26. Rascón-Leon, S., Castillo-Ortega, M. M., Santos-Sauceda, I., Munive, G. T., Rodriguez-Felix, D. E., Castillo-Castro, T., Encinas, J. C., Valenzuela-García, J. L., Quiroz-Castillo, J. M., García-Gaitan, B., Herrera-Franco, P. J., Alvarez-Sanchez, J., Ramírez, J. Z., \& Quiroz-Castillo, L. S. (2018). Selective adsorption of gold and silver in bromine solutions by acetate cellulose composite membranes coated with polyaniline or polypyrrole. Polymer Bulletin, 75(7), 3241-3265. http://dx.doi. org/10.1007/s00289-017-2206-9.
27. Sun, X., Lv, X., Li, X., Yuan, X., Li, L., \& Gu, G. (2018). Fe3O4@SiO2 nanoparticles wrapped with polypyrrole (PPy) aerogel: A highly performance material as excellent electromagnetic absorber. Materials Letters, 221, 93-96. http:// dx.doi.org/10.1016/j.matlet.2018.03.079.

28. Zhou, W., Lu, L., Chen, D., Wang, Z., Zhai, J., Wang, R., Tan, G., Mao, J., Yu, P., \& Ning, C. (2018). Construction of high surface potential polypyrrole nanorods with enhanced antibacterial properties. Journal of Materials Chemistry. B, Materials for Biology and Medicine, 6(19), 3128-3135. http:// dx.doi.org/10.1039/C7TB03085A. PMid:32254347.

29. Wan, C., \& Li, J. (2016). Cellulose aerogels functionalized with polypyrrole and silver nanoparticles: in-situ synthesis, characterization and antibacterial activity. Carbohydrate Polymers, 146, 362-367. http://dx.doi.org/10.1016/j.carbpol.2016.03.081. PMid:27112885.

30. Bideau, B., Bras, J., Saini, S., Daneault, C., \& Loranger, E. (2016). Mechanical and antibacterial properties of a nanocellulose-polypyrrole multilayer composite. Materials Science and Engineering C, 69, 977-984. http://dx.doi. org/10.1016/j.msec.2016.08.005. PMid:27612793.

31. Mandu, M. A. L. G. M. R., Costa, L. D. C., Tiosso, R. B., Grasso, R. P., \& Calderari, M. R. D. C. M. (2019). Evaluation of antimicrobial action of silver composite microspheres based on styrene-divinylbenzene copolymer. Polímeros, 29(4), e2019052. http://dx.doi.org/10.1590/0104-1428.00219.

32. Silva, C. F., Oliveira, F. S. M., Caetano, V. F., Vinhas, G. M., $\&$ Cardoso, S. A. (2018). Orange essential oil as antimicrobial additives in poly(vinyl chloride) films. Polímeros, 28(4), 332338. http://dx.doi.org/10.1590/0104-1428.16216.

33. Majeed, Z., Mushtaq, M., Ajab, Z., Guan, Q., Mahnashi, M. H., Alqahtani, Y. S., \& Ahmad, B. (2020). Rosin maleic anhydride adduct antibacterial activity against methicillin-resistant Staphylococcus aureus. Polimeros, 30(2), e2020022. http:// dx.doi.org/10.1590/0104-1428.03820.

34. Costa, L. C., Mandu, M. A. L. G. M. R., Santa Maria, L. C., \& Marques, M. R. C. (2015). Resinas poliméricas reticuladas com ação biocida: atual estado da arte. Polímeros, 25(4), 414423. http://dx.doi.org/10.1590/0104-14281739.

35. Raza, Z. A., \& Anwar, F. (2018). Fabrication of poly(lactic acid) incorporated chitosan nanocomposites for enhanced functional polyester fabric. Polimeros, 28(2), 120-124. http:// dx.doi.org/10.1590/0104-1428.11216.

36. Varesano, A., Vineis, C., Aluigi, A., Rombaldoni, F., Tonetti, C., \& Mazzuchetti, G. (2013). Antibacterial efficacy of polypyrrole in textile applications. Fibers and Polymers, 14(1), 36-43. http://dx.doi.org/10.1007/s12221-013-0036-4.

37. Seshadri, D. T., \& Bhat, N. V. (2005). Synthesis and properties of cotton fabrics modified with polypyrrole. Journal of Fiber Science and Technology, 61(4), 103-108. http://dx.doi. org/10.2115/fiber.61.103.

38. Sanchez Ramirez, D. O., Varesano, A., Carletto, R. A., Vineis, C., Perelshtein, I., Natan, M., Perkas, N., Banin, E., \& Gedanken, A. (2019). Antibacterial properties of polypyrrole-treated fabrics by ultrasound deposition. Materials Science and Engineering C, 102, 164-170. http://dx.doi.org/10.1016/j.msec.2019.04.016. PMid:31146987.

39. Bin-Jumah, M., Gilani, S. J., Jahangir, M. A., Zafar, A., Alshehri, S., Yasir, M., Kala, C., Taleuzzaman, M., \& Imam, S. S. (2020). Clarithromycin-loaded ocular chitosan nanoparticle: Formulation, optimization, characterization, ocular irritation, and antimicrobial activity. International Journal of Nanomedicine, 15, 7861-7875. http://dx.doi.org/10.2147/IJN.S269004. PMid:33116505.

40. Maruthapandi, M., Saravanan, A., Luong, J. H. T., \& Gedanken, A. (2020). Antimicrobial properties of polyaniline 
and polypyrrole decorated with zinc-doped copper oxide microparticles. Polymers, 12(6), 1286. http://dx.doi.org/10.3390/ polym12061286. PMid:32512800.

41. Sayyah, S. M., Mohamed, F., \& Shaban, M. (2014). Antibacterial activity of nano fabricated polypyrrole by cyclic voltammetry. IOSR Journal of Applied Chemistry, 7(2), 11-15. http://dx.doi. org/10.9790/5736-07211115.

42. Hasantabar, V., Lakouraj, M. M., Nazarzadeh Zare, E., \& Mohseni, M. (2015). Innovative magnetic tri-layered nanocomposites based on polyxanthone triazole, polypyrrole and iron oxide: Synthesis, characterization and investigation of the biological activities. RSC Advances, 5(86), 70186-70196. http://dx.doi. org/10.1039/C5RA07309J.

43. Ahmad, N., Sultana, S., Faisal, S. M., Ahmed, A., Sabir, S., \& Khan, M. Z. (2019). Zinc oxide-decorated polypyrrole/ chitosan bionanocomposites with enhanced photocatalytic, antibacterial and anticancer performance. RSC Advances, 9(70), 41135-41150. http://dx.doi.org/10.1039/C9RA06493A.

44. Salabat, A., Mirhoseini, F., Mahdieh, M., \& Saydi, H. (2015). A novel nanotube-shaped polypyrrole-Pd composite prepared using reverse microemulsion polymerization and its evaluation as an antibacterial agent. New Journal of Chemistry, 39(5), 4109-4114. http://dx.doi.org/10.1039/C5NJ00175G.

45. Zang, L., Qiu, J., Yang, C., \& Sakai, E. (2016). Preparation and application of conducting polymer/Ag/clay composite nanoparticles formed by in situ UV-induced dispersion polymerization. Scientific Reports, 6(1), 20470. http://dx.doi. org/10.1038/srep20470. PMid:26839126.

46. Huxtar, Y., Wang, Y. B., Abibulla, M., Abdukeyum, A., Muhtar, N., $\& \mathrm{Su}, \mathrm{Z}$. (2016). Preparation of composite coatings of spherical hydroxyapatite and silver nanoparticles on biomedical titanium using pulse electrochemical deposition method controlled by pyrrole polymerization. Gaofenzi Xuebao, (4), 528-537. http:// dx.doi.org/10.11777/j.issn1000.3304.2016.15285.

47. Das, R., Giri, S., King Abia, A. L., Dhonge, B., \& Maity, A. (2017). Removal of Noble Metal Ions ( $\mathrm{Ag}+$ ) by Mercapto Group-Containing Polypyrrole Matrix and Reusability of Its Waste Material in Environmental Applications. ACS Sustainable Chemistry \& Engineering, 5(3), 2711-2724. http://dx.doi. org/10.1021/acssuschemeng.6b03008.

48. Shang, M., Wang, W., Zou, H., \& Ren, G. (2016). Coating $\mathrm{Fe} 3 \mathrm{O} 4$ spheres with polypyrrole-Pd composites and their application as recyclable catalysts. Synthetic Metals, 221, 142-148. http://dx.doi.org/10.1016/j.synthmet.2016.08.015.

49. Hasik, M., Drelinkiewicz, A., \& Malata, G. (1999). Studies of polypyrrole - Pd2+ systems. Synthetic Metals, 102(1-3), 1306. http://dx.doi.org/10.1016/S0379-6779(98)00996-5.

50. Ding, K., Jia, H., Wei, S., \& Guo, Z. (2011). Electrocatalysis of sandwich-structured $\mathrm{Pd} /$ polypyrrole/Pd composites toward formic acid oxidation. Industrial \& Engineering Chemistry Research, 50(11), 7077-7082. http://dx.doi.org/10.1021/ ie102392n.

51. Murugesan, B., Pandiyan, N., Arumugam, M., Sonamuthu, J., Samayanan, S., Yurong, C., Yao, J., \& Mahalingam, S. (2020). Fabrication of palladium nanoparticles anchored polypyrrole functionalized reduced graphene oxide nanocomposite for antibiofilm associated orthopedic tissue engineering. Applied Surface Science, 510, 145403. http://dx.doi.org/10.1016/j. apsusc.2020.145403.

52. Adams, C. P., Walker, K. A., Obare, S. O., \& Docherty, K. M. (2014). Size-dependent antimicrobial effects of novel palladium nanoparticles. PLoS One, 9(1), e85981. http:// dx.doi.org/10.1371/journal.pone.0085981. PMid:24465824.

53. Baker, C., Pradhan, A., Pakstis, L., Pochan, D. J., \& Shah, S. I. (2005). Synthesis and antibacterial properties of silver nanoparticles. Journal of Nanoscience and Nanotechnology,
5(2), 244-249. http://dx.doi.org/10.1166/jnn.2005.034. PMid:15853142.

54. Martínez-Castañón, G. A., Niño-Martínez, N., MartínezGutierrez, F., Martínez-Mendoza, J. R., \& Ruiz, F. (2008). Synthesis and antibacterial activity of silver nanoparticles with different sizes. Journal of Nanoparticle Research, 10(8), 1343-1348. http://dx.doi.org/10.1007/s11051-008-9428-6.

55. Shrivastava, S., Bera, T., Roy, A., Singh, G., Ramachandrarao, P., \& Dash, D. (2007). Characterization of enhanced antibacterial effects of novel silver nanoparticles. Nanotechnology, 18(22), 225103. http://dx.doi.org/10.1088/0957-4484/18/22/225103.

56. Liu, F., Yuan, Y., Li, L., Shang, S., Yu, X., Zhang, Q., Jiang, S., \& Wu, Y. (2015). Synthesis of polypyrrole nanocomposites decorated with silver nanoparticles with electrocatalysis and antibacterial property. Composites. Part B, Engineering, 69, 232-236. http://dx.doi.org/10.1016/j.compositesb.2014.09.030.

57. Liu, J., Wang, J., Yu, X., Li, L., \& Shang, S. (2015). One-pot synthesis of polypyrrole/ $\mathrm{AgCl}$ composite nanotubes and their antibacterial properties. Micro \& Nano Letters, 10(1), 50-53. http://dx.doi.org/10.1049/mnl.2014.0435.

58. Upadhyay, J., Kumar, A., Gogoi, B., \& Buragohain, A. K. (2015). Antibacterial and hemolysis activity of polypyrrole nanotubes decorated with silver nanoparticles by an in-situ reduction process. Materials Science and Engineering $C$, 54, 8-13. http://dx.doi.org/10.1016/j.msec.2015.04.027. PMid:26046261.

59. Saad, A., Cabet, E., Lilienbaum, A., Hamadi, S., Abderrabba, M., \& Chehimi, M. M. (2017). Polypyrrole/Ag/mesoporous silica nanocomposite particles: design by photopolymerization in aqueous medium and antibacterial activity. Journal of the Taiwan Institute of Chemical Engineers, 80, 1022-1030. http:// dx.doi.org/10.1016/j.jtice.2017.09.024.

60. Chung, Y. C., \& Chen, C. Y. (2008). Antibacterial characteristics and activity of acid-soluble chitosan. Bioresource Technology, 99(8), 2806-2814. http://dx.doi.org/10.1016/j.biortech.2007.06.044. PMid: 17697776

61. Qi, L., Xu, Z., Jiang, X., Hu, C., \& Zou, X. (2004). Preparation and antibacterial activity of chitosan nanoparticles. Carbohydrate Research, 339(16), 2693-2700. http://dx.doi.org/10.1016/j. carres.2004.09.007. PMid:15519328.

62. Goy, R. C., De Britto, D., \& Assis, O. B. G. (2009). A review of the antimicrobial activity of chitosan. Polimeros, 19(3), 241247. http://dx.doi.org/10.1590/S0104-14282009000300013.

63. Cabuk, M., Alan, Y., Yavuz, M., \& Unal, H. I. (2014). Synthesis, characterization and antimicrobial activity of biodegradable conducting polypyrrole-graft-chitosan copolymer. Applied Surface Science, 318, 168-175. http://dx.doi.org/10.1016/j. apsusc.2014.02.180

64. Talebi, A., Labbaf, S., \& Karimzadeh, F. (2019). A conductive film of chitosan-polycaprolcatone-polypyrrole with potential in heart patch application. Polymer Testing, 75, 254-261. http:// dx.doi.org/10.1016/j.polymertesting.2019.02.029.

65. Kumar, A. M., Suresh, B., Das, S., Obot, I. B., Adesina, A. Y., \& Ramakrishna, S. (2017). Promising bio-composites of polypyrrole and chitosan: surface protective and in vitro biocompatibility performance on 316L SS implants. Carbohydrate Polymers, 173, 121-130. http://dx.doi.org/10.1016/j.carbpol.2017.05.083. PMid:28732850.

66. Soleimani, M., Ghorbani, M., \& Salahi, S. (2016). Antibacterial Activity of Polypyrrole-Chitosan Nanocomposite: mechanism of Action. International Journal of Nanoscience and Nanotechnology, 12(3), 191-197.

67. Ahmed, F., Santos, C. M., Vergara, R. A. M. V., Tria, M. C. R., Advincula, R., \& Rodrigues, D. F. (2012). Antimicrobial applications of electroactive PVK-SWNT nanocomposites. 
Environmental Science \& Technology, 46(3), 1804-1810. http:// dx.doi.org/10.1021/es202374e. PMid:22091864.

68. Liu, X., Wang, M., Zhang, S., \& Pan, B. (2013). Application potential of carbon nanotubes in water treatment: A review. Journal of Environmental Sciences (China), 25(7), 12631280. http://dx.doi.org/10.1016/S1001-0742(12)60161-2. PMid:24218837.

69. Tondro, G. H., Behzadpour, N., Keykhaee, Z., Akbari, N., \& Sattarahmady, N. (2019). Carbon@polypyrrole nanotubes as a photosensitizer in laser phototherapy of Pseudomonas aeruginosa. Colloids and Surfaces. B, Biointerfaces, 180, 481-486. http://dx.doi.org/10.1016/j.colsurfb.2019.05.020. PMid:31102852.

70. Robertson, J., Gizdavic-Nikolaidis, M., Nieuwoudt, M. K., $\&$ Swift, S. (2018). The antimicrobial action of polyaniline involves production of oxidative stress while functionalisation of polyaniline introduces additional mechanisms. PeerJ, 6:136. https://doi.org/10.7717/peerj.5135

71. Ghaffari-Moghaddam, M., \& Eslahi, H. (2014). Synthesis, characterization and antibacterial properties of a novel nanocomposite based on polyaniline/polyvinyl alcohol/Ag. Arabian Journal of Chemistry, 7(5), 846-855. http://dx.doi. org/10.1016/j.arabjc.2013.11.011.

72. Kucekova, Z., Humpolicek, P., Kasparkova, V., Perecko, T., Lehocký, M., Hauerlandová, I., Sáha, P., \& Stejskal, J. (2014). Colloidal polyaniline dispersions: antibacterial activity, cytotoxicity and neutrophil oxidative burst. Colloids and Surfaces. B, Biointerfaces, 116, 411-417. http://dx.doi. org/10.1016/j.colsurfb.2014.01.027. PMid:24534430.

73. Ebrahimiasl, S., Zakaria, A., Kassim, A., \& Basri, S. N. (2015). Novel conductive polypyrrole/zinc oxide/chitosan bionanocomposite: Synthesis, characterization, antioxidant, and antibacterial activities. International Journal of Nanomedicine, 10, 217-227. http://dx.doi.org/10.2147/IJN.S69740. PMid:25565815.

74. Kumar, R., Oves, M., Almeelbi, T., Al-Makishah, N. H., \& Barakat, M. A. (2017). Hybrid chitosan/polyaniline-polypyrrole biomaterial for enhanced adsorption and antimicrobial activity. Journal of Colloid and Interface Science, 490, 488-496. http:// dx.doi.org/10.1016/j.jcis.2016.11.082. PMid:27918986.

75. Salam, M. A., Obaid, A. Y., El-Shishtawy, R. M., \& Mohamed, S. A. (2017). Synthesis of nanocomposites of polypyrrole/ carbon nanotubes/silver nano particles and their application in water disinfection. RSC Advances, 7(27), 16878-16884. http://dx.doi.org/10.1039/C7RA01033H.

76. Stejskal, J., \& Trchová, M. (2018). Conducting polypyrrole nanotubes: a review. Chemical Papers, 72(7), 1563-1595. http://dx.doi.org/10.1007/s11696-018-0394-x.

77. Balint, R., Cassidy, N. J., \& Cartmell, S. H. (2014). Conductive polymers: towards a smart biomaterial for tissue engineering. Acta Biomaterialia, 10(6), 2341-2353. http://dx.doi.org/10.1016/j. actbio.2014.02.015. PMid:24556448.

78. Liao, Z., Fang, X., Li, J., Li, X., Zhang, W., Sun, X., Shen, J., Han, W., Zhao, S., \& Wang, L. (2018). Incorporating organic nanospheres into the polyamide layer to prepare thin film composite membrane with enhanced biocidal activity and chlorine resistance. Separation and Purification Technology, 207, 222-230. http://dx.doi.org/10.1016/j.seppur.2018.06.057.

79. Wu, C. S. (2011). Polyester and multiwalled carbon nanotube composites: Characterization, electrical conductivity and antibacterial activity. Polymer International, 60(5), 807-815. http://dx.doi.org/10.1002/pi.3022.

Received: Aug. 26, 2020

Revised: Nov. 21, 2020

Accepted: Dec. 08, 2020 